\title{
Effect of Extraction Technique on Composition of Volatile Constituents of Oleoresin from Pinus Brutia Ten.
}

\section{Utjecaj tehnike ekstrakcije na sastav hlapljivih sastojaka oleoresina iz drva Pinus brutia Ten.}

\author{
Original scientific paper • Izvorni znanstveni rad \\ Received-prispjelo: 28. 9. 2017. \\ Accepted-prihvaćeno: 13. 6. 2018. \\ UDK: $630 * 813.4 ; 630 * 874.1 ; 674.032 .475 .4$ \\ doi:10.5552/drind.2018.1754
}

\begin{abstract}
In this study, volatile constituents of oleoresin from Pinus brutia Ten. were extracted by solid phase microextraction (SPME) and hydrodistillation. Gas chromatography-mass spectroscopy (GC/MS) was performed to determine volatile constituents of turpentine oil (obtained by hydrodistillation) and extract from oleoresin (obtained by SPME). Eleven volatile compounds constituted the total of turpentine oil obtained by hydrodistillation, whereas SPME extract contained 32 volatile compounds. Three distinctive volatile constituents in the turpentine oil were $\alpha$-pinene $(49.12 \%)$, $\beta$-pinene $(19.12 \%)$ and $\Delta^{3}$-carene $(15.33 \%)$. They were represented in the amount of $44.35 \%, 18.59 \%$ and $14.58 \%$ in the SPME extract. The volatile constituents of turpentine oil were monoterpenes and sesquiterpenes. Monoterpenes, sesquiterpenes, terpene oxides, alcohols, aldehydes, esters and ethers were identified as main groups in the SPME extract by GC/MS. The results of chromatographic analysis showed that solid phase microextraction was a more effective extraction technique than hydrodistillation for isolating volatile constituents from oleoresin.
\end{abstract}

Keywords: volatile constituents, oleoresin, hydrodistillation, solid phase microextraction (SPME), GC/MS

SAŽETAK • Za ovu su studiju hlapljivi sastojci oleoresina iz drva Pinus brutia Ten. izdvojeni mikroekstrakcijom čvrste faze (SPME) i hidrodestilacijom. Radi određivanja hlapljivih sastojaka terpentinskog ulja (dobivenoga hidrodestilacijom) i ekstrakta oleoresina (dobivenoga SPME-om), provedena je plinska kromatografija i masena spektrometrija (GC/MS). Jedanaest hlapljivih spojeva sadržavalo je terpentinsko ulje dobiveno hidrodestilacijom, dok je ekstrakt dobiven SPME-om sadržavao 32 hlapljiva spoja. Tri karakteristična hlapljiva sastojka u terpentinskom ulju bila su $\alpha$-pinene (49,12\%), $\beta$-pinene (19,12\%) i $\Delta^{3}$-karen (15,33\%). Ti su spojevi u ekstraktu SPME-a bili zastupljeni u udjelu od 44,35, 18,59 i 14,58\%. Hlapljivi sastojci terpentinskog ulja bili su monoterpeni i seskviterpeni, a kao glavne skupine u ekstraktu SPME-a uz pomoć GC/MS metode identificirani su monoterpeni, seskviterpeni, terpenski oksidi, alkoholi, aldehidi, esteri i eteri. Rezultati kromatografske analize pokazali su da je za izolaciju hlapljivih sastojaka oleoresina mikroekstrakcija čvrste faze učinkovitija tehnika ekstrakcije od hidrodestilacije.

Ključne riječi: hlapljivi sastojci, oleoresin, hidrodestilacija, mikroekstrakcija čvrste faze (SPME), GC/MS

\footnotetext{
${ }^{1}$ Authors are professor and research assistants at Department of Forest Products Engineering, Faculty of Forestry, Isparta University of Applied Sciences, Isparta, Turkey.

Autori su profesor i znanstveni asistenti Odjela za tehnologiju proizvoda od drva, Šumarski fakultet, Isparta University of Applied Sciences, Isparta, Turska.
} 


\section{INTRODUCTION}

\section{UVOD}

Oleoresin is obtained as exudates from pine trees by tapping the bark (bark chipping). Turpentine, essential oil, is produced by steam/hydro distillation from oleoresin. Turpentine is also known commercially as the "spirits of turpentine", "pine tree terpenic", "pine oleoresin", "gum turpentine", "terpenes oil", "turpentine from Bordeaux" or "oil of turpentine". $\alpha$-pinene and $\beta$-pinene are the major constituents of turpentine. Pinenes are mostly used as starting materials to produce more valuable components (Jantam and Ahmad, 1999; McMorn et al., 2000; Rezzi et al., 2005; Wang et al., 2006; Limberger et al., 2007; Mercier et al., 2009). Besides pinenes, turpentine contains other terpenes such as camphene, $\Delta^{3}$-carene, tricyclene, myrcene, $p$ cymene, limonene, $\beta$-caryophyllene and aromadendrene. Moreover, turpentine compounds are useful raw material for the production of pharmaceuticals, plasticizers, repellents, insecticides, solvents, perfumery, food additives, antiviral, antimicrobial and antioxidant compounds (Roberge et al., 2001; Macchioni et al., 2003; Sun, 2007; Burdock and Carabin, 2008; Mayekiso et al., 2008; Behr and Johnen, 2009; Zulak and Bohlmann, 2010; Adams et al., 2011; Teshome, 2011; Back et al., 2012; Rudback et al., 2012; Gillette et al., 2012; Limberger et al., 2012).

Brutian pine (Pinus brutia Ten.) is especially used for the production of oleoresin in Turkey $(\mathrm{Oz}$ et al., 2012; Deniz, 2013; Oz et al., 2015). It grows widely in the Mediterranean region, Aegean region, Marmara region and also in some localities of the western Black Sea region in a total area of about 5.8 million ha in Turkey (OGM, 2015).

Solid phase microextraction (SPME) is a sampling technique, whereby a constituent is adsorbed onto the surface of the coated silica fiber. Afterwards, constituents are desorbed into a suitable chromatography instrument coupled with an appropriate detector for identification and quantification. SPME is usually performed by gas chromatography (GC) in the applications. In SPME$\mathrm{GC}$ analysis, the fiber is introduced into the injection port of GC device and constituents are thermally desorbed from the coating for chromatographically determination (Malik et al., 2006). SPME was especially applied in environmental chemistry (Fattore et al., 1996; Abalos et al., 2002; Mousavi et al., 2007), for example for determining organic pollutants in environmental samples (Penalver et al., 1999) and phthalate esters in environmental waters (Polo et al., 2005). It was regularly used to isolate volatile and semivolatile components (Zhang and Pawliszyn, 1993; James and Stack, 1996), for example for determining volatile components of some medicinal and aromatic plants (Bicchi et al., 2007; Yasar et al., 2016) and semivolatile organics in environmental solids (Hageman et al., 1999).

The determination of volatile constituents of oleoresin, after isolation of turpentine oil by hydrodistillation, is a commonly used procedure (Rezzi et al., 2005; Wang et al., 2006; Tümen and Reunanen, 2010;
Oz et al., 2015). Besides hydrodistillation technique, the volatile constituents of oleoresin were isolated from brutian pine using SPME in this study. This was followed by determination of volatile constituents of turpentine oil (obtained by hydrodistillation) and extract (obtained by SPME) by gas chromatographymass spectroscopy (GC/MS). Finally, both applications were compared to reveal which extraction technique is more effective for isolating the volatile constituents of oleoresin.

\section{MATERIALS AND METHODS}

\section{MATERIJALI I METODE}

\subsection{Materials}

2.1. Materijali

Oleoresin of brutian pine (Pinus brutia Ten.) was obtained from Karaisali-Adana $\left(37^{\circ} 17^{\prime} 40.0^{\prime \prime} \mathrm{N}\right.$ $\left.35^{\circ} 09^{\prime} 15.0^{\prime} \mathrm{E}\right)$ in Turkey. Tapping was applied using an acid paste method after bark chipping. The bark of each tree was chipped $10 \mathrm{~cm}$ in width and $5 \mathrm{~cm}$ in height using a wounding apparatus at $1 \mathrm{~m}$ height above ground. Afterwards, a collector was placed under the wound for gathering flowed oleoresin and the chemical stimulant. The acid paste was applied as chemical stimulant using plastic injectors. Acid paste contained $65 \%$ solution of sulphuric acid, coal, dust, barley-rice bran and dyotamide soil. Sample trees were aged 35, 35 and 37 years, and they were 16, 17 and 18 meters in height and 30, 35 and $38 \mathrm{~cm}$ in diameter.

\subsection{SPME and GC/MS analysis}

\subsection{SPME i GC/MS analiza}

The solid phase microextraction (SPME) apparatus, equipped with a fiber coated and a $75 \mu \mathrm{m}$-thick layer of Carboxen/Polydimethylsiloxane (CAR/PDMS), was used for the isolation of volatile constituents from oleoresin. $2 \mathrm{~g}$ of oleoresin were used in the experiment. Firstly, oleoresin was placed in a $10 \mathrm{~mL}$ vial, which was sealed with a silicone septum and a crimp cap and heated at $60{ }^{\circ} \mathrm{C}$ for $15 \mathrm{~min}$. Secondly, SPME fiber was pushed through the headspace of a sample vial. The volatile constituents were adsorbed at $60{ }^{\circ} \mathrm{C}$ for $30 \mathrm{~min}$. Then fiber was inserted directly into the injection port of the Shimadzu 2010 Plus GC/MS. GC/MS device was equipped with a Restek Rx-5Sil MS capillary column (30 m x $0.25 \mathrm{~mm}$ i.d., $0.25 \mu \mathrm{m}$ film thickness) coupled to a mass spectrometer with an ion trap detector in full scan under electron impact ionization $(70 \mathrm{eV})$. Helium was used as carrier gas with a flow rate of $1.61 \mathrm{~mL} / \mathrm{min}$. The injection and detection were performed at the temperature of $250{ }^{\circ} \mathrm{C}$. Quadrupole temperature was also $250{ }^{\circ} \mathrm{C}$. Mass range was between 35 and $450 \mathrm{~m} / \mathrm{z}$. The temperature of column was kept at $40^{\circ} \mathrm{C}$ for $2 \mathrm{~min}$, subsequently raised to $250{ }^{\circ} \mathrm{C}$ at a rate of $4{ }^{\circ} \mathrm{C} / \mathrm{min}$ and then held at $250^{\circ} \mathrm{C}$ for $5 \mathrm{~min}$. The software used was LabSolutions GCMSsolution Version 2.7.

\subsection{Isolation of turpentine oil and GC/MS analysis} 2.3. Izolacija terpentinskog ulja i GC/MS analiza

For the isolation of turpentine oil, $100 \mathrm{~g}$ of oleoresin were submitted to hydrodistillation for $5 \mathrm{~h}$ using 
Table 1 Extraction parameters for hydrodistillation and SPME

Tablica 1. Parametri ekstrakcije za hidrodestilaciju i SPME analizu

\begin{tabular}{|l|c|c|c|}
\hline $\begin{array}{c}\text { Extraction type } \\
\text { Vrsta ekstrakcije }\end{array}$ & $\begin{array}{c}\text { Time } \\
\text { Vrijeme } \\
\text { min }\end{array}$ & $\begin{array}{c}\text { Sample weight } \\
\text { Masa uzorka } \\
\mathrm{g}\end{array}$ & $\begin{array}{c}\text { Solvent } \\
\text { Otapalo }\end{array}$ \\
\hline Hydrodistillation / hidrodestilacija & 300 & 100 & Distilled water / Destilirana voda \\
\hline SPME Sampling / SPME uzorkovanje & 45 & 2 & - \\
\hline
\end{tabular}

a Clevenger-type apparatus. Hydrodistillation yielded $30.4 \%$ (w/w) turpentine oil from oleoresin. $30 \mu \mathrm{L}$ turpentine oil were added to $970 \mu \mathrm{L}$ hexane (GC grade) and $1 \mu \mathrm{L}$ of this solution was submitted to injection port of GC/MS. GC/MS was performed under the same conditions as described above.

\subsection{Identification of constituents \\ 2.4. Identifikacija sastojaka}

Retention indices of volatile constituents were determined using a series of saturated $n$-alkanes. $n$-alkanes were injected after each sample at the same chromatographic conditions as described above for GC/MS. The volatile constituents were identified by comparison of their mass spectra with the Wiley, NIST, Tutor and FFNSC libraries or with data already available in the literature (Adams, 2007). Percentage amounts were calculated based on peak areas from the GC/MS chromatogram by the computer software described above.

\subsection{Statistical analysis}

\subsection{Statistička analiza}

MiniTab 16 software was used for statistical analyses. Independent samples $t$ test analysis was applied to determine the statistical significance. For each variable, independent samples $t$ test was separately done.

\section{RESULTS AND DISCUSSION}

\section{REZULTATI I RASPRAVA}

SPME was definitely a more efficient sample preparation technique as compared to classical hydrodistillation, and it could be performed with a much smaller amount of oleoresin than hydrodistillation (Table 1). For this reason, SPME technique offers more advantages than conventional hydrodistillation for extraction.

GC/MS chromatograms of volatile constituents of turpentine oil obtained by hydrodistillation and extract obtained by SPME from oleoresin of Pinus brutia Ten. are demonstrated in Figure 1 and 2.

Identified volatile constituents of turpentine oil and SPME extract of oleoresin from Pinus brutia Ten. are given in Table 2. Through the application of SPME for the extraction of volatile compounds from oleoresin, it was possible to determine a total of 32 compounds by direct injection on GC/MS. $\alpha$-pinene, $\beta$-pinene and $\Delta^{3}$-carene were the major constituents $(44.35 \%, 18.59$ $\%$ and $14.58 \%$, respectively) of oleoresin. According to GC/MS analysis of the hydrodistilled turpentine oil, a total of 11 volatile constituents were characterized. At the highest percentage of monoterpenes, they were represented by $\alpha$-pinene (49.12\%), $\beta$-pinene (19.2\%) and $\Delta^{3}$-carene $(15.33 \%)$.

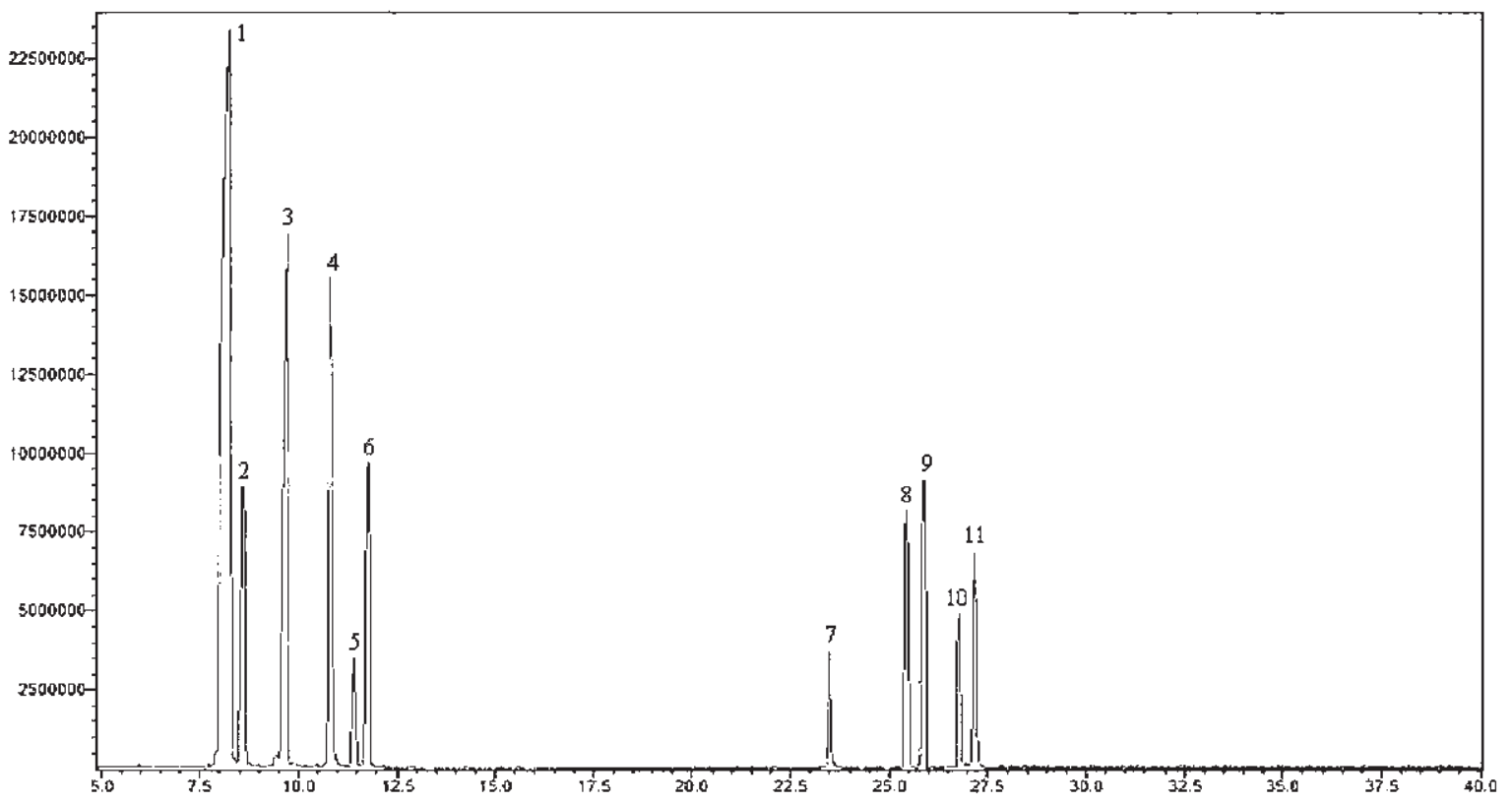

Figure $1 \mathrm{GC} / \mathrm{MS}$ chromatogram of turpentine oil obtained by hydrodistillation of oleoresin from Pinus brutia Ten. (1: $\alpha$-pinene, 2: camphene, 3: $\beta$-pinene, 4: $\Delta^{3}$-carene, 5: $p$-cymene, 6: limonene, 7: $\alpha$-cubebene, $8: \alpha$-gurjunene, 9 : $\beta$-caryophyllene, 10 : aromadendrene, 11: $\alpha$-humulene)

Slika 1. GC/MS kromatogram terpentinskog ulja dobivenoga hidrodestilacijom oleoresina iz drva Pinus brutia Ten. (1: $\alpha$-pinen, 2: camfen, 3: $\beta$-pinen, 4: $\Delta^{3}$-karen, 5: $p$-cimen, 6: limonen, 7: $\alpha$-kubeben, 8: $\alpha$-gurjunen, 9: $\beta$-kariofilen, 10: aromadendren, 11 : $\alpha$-humulen) 


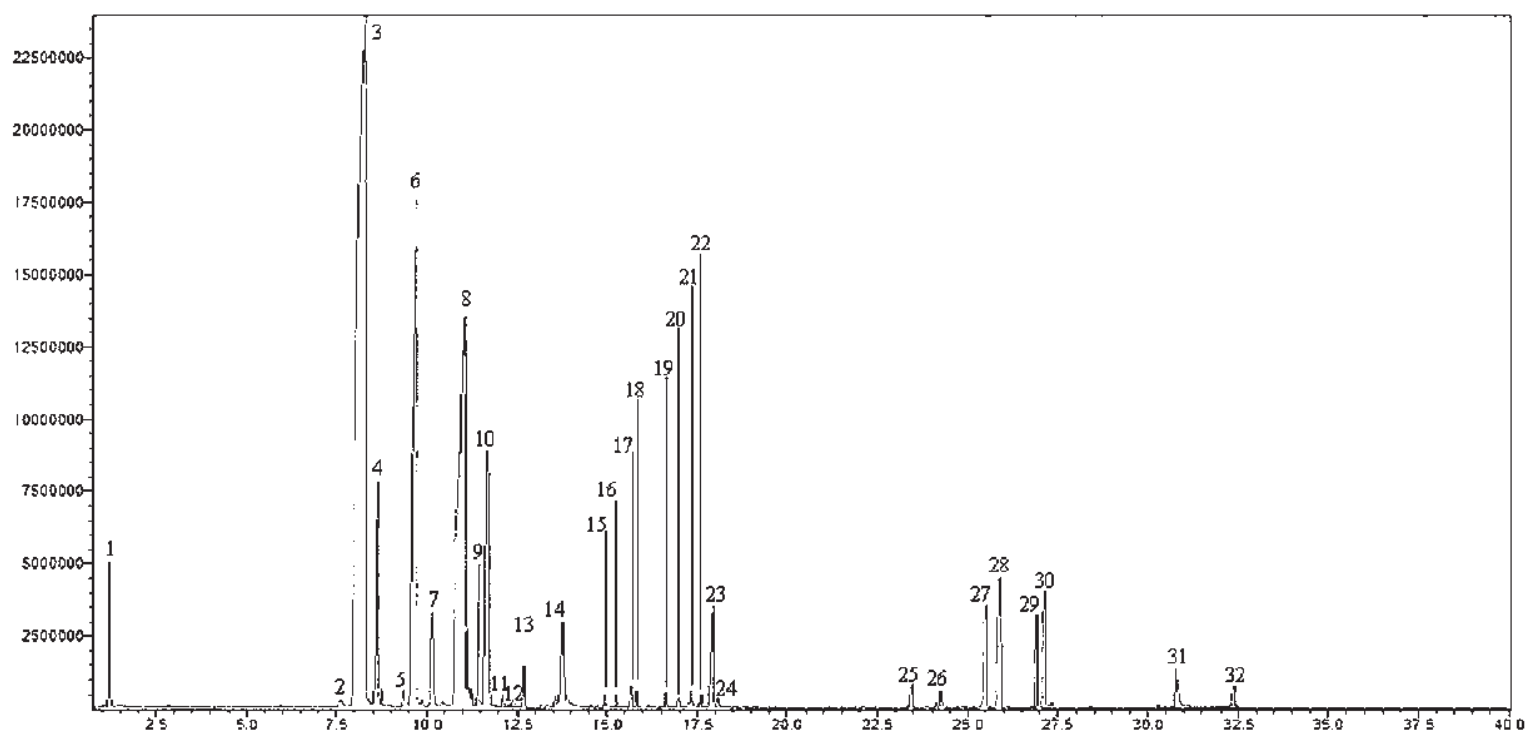

Figure 2 GC/MS chromatogram of SPME extract of oleoresin from Pinus brutia Ten. (1: isopropyl acetate, 2: tricyclene, 3 : $\alpha$-pinene, 4: camphene, 5: benzaldehyde, 6: $\beta$-pinene, 7: myrcene, 8: $\Delta^{3}$-carene, 9: $p$-cymene, 10: limonene, 11: butyl 2-methylbutyrate, 12: (E)- $\beta$-ocimene, 13: $\gamma$-terpinene, 14: $p$ - $\alpha$-dimethylstyrene, 15: 2.4-dimethylanisole, 16 : $\alpha$-campholene aldehyde, 17: terpin-3-en-1-ol, 18: trans- $\beta$-terpineol, 19: trans-limonene oxide, 20: isoborneol, 21: terpinen-4-ol, 22: $p$-cymen-8-ol, 23 : $\alpha$-terpineol, 24: verbenone, 25: $\alpha$-cubebene, 26: cyclosativene, 27: $\alpha$-gurjunene, 28 : $\beta$-caryophyllene, 29: aromadendrene, 30 : $\alpha$-humulene, 31: caryophyllene oxide, 32: humulene oxide)

Slika 2. GC/MS kromatogram SPME ekstrakta oleoresina iz drva Pinus brutia Ten. (1: izopropil acetat, 2: triciklen, 3: $\alpha$-pinen, 4: kamfen, 5: benzaldehid, 6: $\beta$-pinen, 7: mircen, 8: $\Delta^{3}$-karen, 9: $p$-cimen, 10: limonen, 11: butil 2-metilbutirat, 12: (E)- $\beta$ ocimen, 13: $\gamma$-terpinen, 14: $p$ - $a$-dimetilstiren, 15: 2,4-dimetilanisol, 16: a-kamfolen aldehid, 17: terpin-3-en-1-ol, 18: trans- $\beta$ -terpineol, 19: trans-limonen oksid, 20: izoborneol, 21: terpinen-4-ol, 22: $p$-cimen-8-ol, 23: $a$-terpineol, 24: verbenon, 25: $a$ kuben, 26: ciklosativen, 27: $a$-gurjunen, 28: $\beta$-kariofilen, 29: aromadendren, 30: $a$-humulen, 31: kariofilen oksid, 32: humulen oksid)

$\alpha$-pinene, camphene, $\beta$-pinene, $\Delta^{3}$-carene, $p$-cymene, limonene, $\quad \alpha$-cubebene, $\alpha$-gurjunene, $\beta$-caryophyllene, aromadendrene and $\alpha$-humulene constituted the total of turpentine oil by hydrodistillation, whereas these compounds appeared as $90.25 \%$ in the extract by SPME. The present findings show that $9.75 \%$ of volatile constituents cannot be extracted by hydrodistillation of oleoresin from Pinus brutia Ten.

According to independent samples $t$ test, a significant difference was found between hydrodistillation and SPME sampling for $\alpha$-pinene, camphene, $p$ cymene, $\alpha$-cubebene, $\alpha$-gurjunene, $\beta$-caryophyllene and aromadendrene $(p<0.05)$. However, there was no significant variance between hydrodistillation and SPME sampling for $\beta$-pinene, $\Delta^{3}$-carene, limonene and $\alpha$-humulene $(p>0.05)$ (Table 2).

The present chemical composition of volatile compounds in the turpentine oil sample from Pinus brutia Ten. [ $\alpha$-pinene (49.12\%), $\beta$-pinene (19.12\%), $\Delta^{3}$-carene $(15.33 \%)$, other monoterpenes $(6.79 \%)$ and sesquiterpenes $(9.56 \%)]$ is higher than findings by $\mathrm{Pa}$ pajannopoulos et al. (2001), who determined $\alpha$-pinene $(13.7 \%), \beta$-pinene $(5.1 \%)$, and other terpenes $(4.5 \%)$ using GC/MS and $\alpha$-pinene $(8.47 \%)$, $\beta$-pinene $(2.99$ $\%), \Delta^{3}$-carene $(3.37 \%)$ and other terpenes $(1.49 \%)$ using GC.

The findings by Ulukanli et al. (2014) were comparable with this study. They found $\alpha$-pinene $(25.4 \%)$, $\beta$-pinene $(9.69 \%)$ and $\Delta^{3}$-carene $(0.16 \%)$ in the turpentine oil sample from Pinus brutia Ten.
Oz et al. (2015) determined, as major compounds, $\alpha$-pinene, $\beta$-pinene and $\gamma$-terpinene with quantities of $19.7 \%, 13.3 \%$ and $10.2 \%$ in the turpentine oil of oleoresin from Pinus brutia Ten. These results support the present findings except for $\gamma$-terpinene and $\Delta^{3}$ carene. $\gamma$-terpinene was not obtained in the turpentine oil of this study. $\Delta^{3}$-carene was presented as $3.7 \%$ in the work by Oz et al. (2015), whereas $\Delta^{3}$-carene was determined as a major compound in the turpentine oil of this study.

The main groups of determined volatile constituents of turpentine oil and SPME extract from oleoresin of Pinus brutia Ten. are listed in Table 3. Monoterpenes and sesquiterpenes were identified in the turpentine oil, whereas monoterpenes, sesquiterpenes, terpene oxides, alcohols, aldehydes, esters and ethers were characterized in the extract by SPME. Based on independent samples $t$ test, a significant difference was found between hydrodistillation and SPME sampling for monoterpenes and sesquiterpenes $(p<0.05)$.

\section{CONCLUSIONS}

4. ZAKLJUČAK

Using SPME for the extraction from oleoresin, 32 volatile constituents were determined by direct injection in GC/MS, whereas 11 volatile constituents were identified in the turpentine oil by GC/MS after hydrodistillation of oleoresin from Pinus brutia Ten. Three major volatile constituents in the turpentine oil were $\alpha$-pinene 
Table 2 Volatile constituents of turpentine oil and SPME extract from oleoresin of Pinus brutia Ten.

Tablica 2. Hlapljivi sastojci terpentinskog ulja i SPME ekstrakta iz oleoresina iz drva Pinus brutia Ten.

\begin{tabular}{|c|c|c|c|c|c|c|c|}
\hline \multirow[t]{2}{*}{ No } & \multirow[t]{2}{*}{$\mathbf{R} \mathbf{I}^{\mathrm{A}}$} & \multirow{2}{*}{$\begin{array}{c}\text { Compound } \\
\text { Sastojak }\end{array}$} & \multirow{2}{*}{$\begin{array}{c}\text { Hydrodistillation } \\
\text { Hidrodestilacija } \\
\%^{\mathrm{B}} \\
\end{array}$} & \multirow{2}{*}{$\begin{array}{c}\text { SPME Sampling } \\
\text { SPME uzorkovanje } \\
\%^{\mathrm{B}}\end{array}$} & \multicolumn{3}{|c|}{$\begin{array}{c}\boldsymbol{t} \text {-test results } \\
\text { Rezultati } t \text {-testa }\end{array}$} \\
\hline & & & & & $F$ & $t$ & $p$ \\
\hline 1 & 635 & isopropyl acetate & - & $1.72(0.06)^{*}$ & - & - & - \\
\hline 2 & 918 & tricyclene & - & $0.26(0.04)$ & - & - & - \\
\hline 3 & 937 & $\alpha$-pinene & $49.12^{\mathrm{a}}(0.65)$ & $44.35^{\mathrm{b}}(1.09)$ & 0.466 & 5.323 & 0.0060 \\
\hline 4 & 947 & camphene & $2.74^{\mathrm{c}}(0.18)$ & $2.17^{\mathrm{d}}(0.12)$ & 0.276 & 3.708 & 0.0207 \\
\hline 5 & 956 & benzaldehyde & - & $0.17(0.03)$ & - & - & - \\
\hline 6 & 975 & $\beta$-pinene & $19.12^{\mathrm{e}}(0.52)$ & $18.59^{\mathrm{e}}(0.13)$ & 2.118 & 1.392 & 0.2365 \\
\hline 7 & 989 & myrcene & - & $1.45(0.05)$ & - & - & - \\
\hline 8 & 1010 & $\Delta^{3}$-carene & $15.33^{\mathrm{f}}(0.44)$ & $14.58^{\mathrm{f}}(0.35)$ & 0.102 & 1.882 & 0.1330 \\
\hline 9 & 1023 & $p$-cymene & $1.10^{\mathrm{g}}(0.11)$ & $1.47^{\mathrm{h}}(0.12)$ & 0.041 & -3.229 & 0.0320 \\
\hline 10 & 1029 & limonene & $3.03^{\mathrm{i}}(0.20)$ & $3.11^{\mathrm{i}}(0.16)$ & 0.066 & -0.444 & 0.6803 \\
\hline 11 & 1040 & butyl 2-methylbutyrate & - & $0.15(0.03)$ & - & - & - \\
\hline 12 & 1045 & $(\mathrm{E})$ - $\beta$-ocimene & - & $0.03(0.01)$ & - & - & - \\
\hline 13 & 1056 & $\gamma$-terpinene & - & $0.53(0.05)$ & - & - & - \\
\hline 14 & 1088 & $p$ - $\alpha$-dimethylstyrene & - & $1.11(0.03)$ & - & - & - \\
\hline 15 & 1113 & 2.4-dimethylanisole & - & $0.16(0.03)$ & - & - & - \\
\hline 16 & 1121 & $\alpha$-campholene aldehyde & - & $0.19(0.03)$ & - & - & - \\
\hline 17 & 1133 & terpin-3-en-1-ol & - & $0.39(0.07)$ & - & - & - \\
\hline 18 & 1136 & trans- $\beta$-terpineol & - & $0.25(0.02)$ & - & - & - \\
\hline 19 & 1159 & trans-limonene oxide & - & $0.17(0.02)$ & - & - & - \\
\hline 20 & 1168 & isoborneol & - & $0.14(0.03)$ & - & - & - \\
\hline 21 & 1177 & terpinen-4-ol & - & $0.21(0.03)$ & - & - & - \\
\hline 22 & 1184 & $p$-cymen-8-ol & - & $0.17(0.05)$ & - & - & - \\
\hline 23 & 1193 & $\alpha$-terpineol & - & $1.51(0.07)$ & - & - & - \\
\hline 24 & 1202 & verbenone & - & $0.14(0.01)$ & - & - & - \\
\hline 25 & 1347 & $\alpha$-cubebene & $1.24^{\mathrm{i}}(0.19)$ & $0.32^{\mathrm{k}}(0.14)$ & 0.176 & 5.571 & 0.0051 \\
\hline 26 & 1370 & cyclosativene & - & $0.26(0.04)$ & - & - & - \\
\hline 27 & 1406 & $\alpha$-gurjunene & $2.39^{1}(0.23)$ & $1.15^{\mathrm{m}}(0.16)$ & 0.283 & 6.347 & 0.0032 \\
\hline 28 & 1418 & $\beta$-caryophyllene & $2.80^{\mathrm{n}}(0.09)$ & $1.73^{\circ}(0.05)$ & 0.637 & 14.791 & 0.0001 \\
\hline 29 & 1444 & aromadendrene & $1.42^{\mathrm{p}}(0.12)$ & $1.11^{\mathrm{r}}(0.05)$ & 1.241 & 3.324 & 0.0293 \\
\hline 30 & 1452 & $\alpha$-humulene & $1.71^{\mathrm{s}}(0.10)$ & $1.67^{\mathrm{s}}(0.12)$ & 0.098 & 0.361 & 0.7366 \\
\hline 31 & 1581 & caryophyllene oxide & - & $0.45(0.07)$ & - & - & - \\
\hline 32 & 1604 & humulene oxide & - & $0.29(0.02)$ & - & - & - \\
\hline
\end{tabular}

A - Retention indices calculated against $n$-alkanes / indeksi zadržavanja izračunani prema n-alkanima; B - Percentages calculated from GC/ MS data. / postotci izračunani iz GC/MS podataka; a-s - Variances according to $t$ test / varijance prema t-testu; * Standard deviations / standardne devijacije

(49.12\%), $\beta$-pinene $(19.12 \%)$ and $\Delta^{3}$-carene $(15.33 \%)$. They were represented by the amounts of $44.35 \%$, $18.59 \%$ and $14.58 \%$ in oleoresin volatiles isolated by
SPME. Monoterpenes and sesquiterpenes were determined in the turpentine oil, while monoterpenes, sesquiterpenes, terpene oxides, alcohols, aldehydes, esters and

Table 3 Main groups of determined constituents of turpentine oil and SPME extract from oleoresin of Pinus brutia Ten. Tablica 3. Glavne skupine određenih sastojaka terpentinskog ulja i SPME ekstrakta iz oleoresina drva Pinus brutia Ten.

\begin{tabular}{|c|c|c|c|c|c|c|}
\hline \multirow{2}{*}{ No } & $\begin{array}{c}\text { Main group } \\
\text { Glavna skupina }\end{array}$ & $\begin{array}{c}\text { Hydrodistillation } \\
\text { Hidrodestilacija } \\
\%\end{array}$ & $\begin{array}{c}\text { SPME Sampling } \\
\text { SPME uzorkovanje } \\
\text { \% }\end{array}$ & \multicolumn{3}{|c|}{$\begin{array}{c}\text { t-test results } \\
\text { Rezultati } \text {-testa }\end{array}$} \\
\cline { 5 - 7 } & $\begin{array}{c}\text { Monoterpene monoter- } \\
\text { pen }\end{array}$ & $90.44^{\mathrm{a}}(1.08)^{*}$ & $87.79^{\mathrm{b}}(0.22)$ & 2.429 & 3.407 & 0.0271 \\
\hline 2 & $\begin{array}{c}\text { Sesquiterpene } \\
\text { seskviterpen }\end{array}$ & $9.56^{\mathrm{c}}(0.56)$ & $6.24^{\mathrm{d}}(0.35)$ & 0.386 & 7.147 & 0.0020 \\
\hline 3 & $\begin{array}{c}\text { Terpene oxide } \\
\text { terpen oksid }\end{array}$ & - & $0.91(0.05)$ & - & - & - \\
\hline 4 & Alcohol / alkohol & - & $2.67(0.09)$ & - & - & - \\
\hline 5 & Aldehyde / aldehid & - & $0.36(0.03)$ & - & - & - \\
\hline 6 & Ester / ester & - & $1.87(0.06)$ & - & - & - \\
\hline 7 & Ether / eter & - & $0.16(0.04)$ & - & - & - \\
\hline
\end{tabular}

a-d - Variances according to $t$ test / varijance prema t-testu; $*$ Standard deviations / standardne devijacije 
ethers were identified as main groups in the extract by SPME. Regarding the quantities of identified volatile compounds occurring in resin of Pinus brutia Ten., SPME has been shown as a more appropriate extraction technique than conventional hydrodistillation.

\section{REFERENCES}

\section{LITERATURA}

1. Abalos, M.; Prieto, X.; Bayona, J. M., 2002: Determination of volatile alkyl sulfides in wastewater by headspace solid-phase microextraction followed by gas chromatography-mass spectrometry. J. Chromatogr. A, 963: 249257. https://doi.org/10.1016/s0021-9673(02)00543-5

2. Adams, R. P., 2007: Identification of essential oil components by gas chromatography/mass spectroscopy. IL, USA: Allured Publishing Corporation: Carol Stream. https://doi.org/10.1016/s1044-0305(97)00026-3

3. Adams, T. B.; Gavin, C. L.; McGowen, M. M.; Waddell, W. J.; Cohen, S. M.; Feron, V. J.; Marnett, L. J.; Munro, I. C.; Portoghese, P. S.; Rietjens, I. M.; Smith, R. L., 2011: The FEMA GRAS assessment of aliphatic and aromatic terpene hydrocarbons used as flavor ingredients. Food Chem. Toxicol., 49: 2471-2494.

https://doi.org/10.1016/j.fct.2011.06.011

4. Back, J.; Aalto, J.; Henriksson, M.; Hakola, H.; He, Q.; Boy, M., 2012: Chemodiversity of a Scots pine stand and implications for terpene air concentrations. Biogeosciences, 9: 689-702.

https://doi.org/10.5194/bg-9-689-2012

5. Behr, A., Johnen, L., 2009: Myrcene as a natural base chemical in sustainable chemistry: a critical review. ChemSus Chem., 2: 1072-1095.

https://doi.org/10.1002/cssc.200900186

6. Bicchi, C.; Cordero, C.; Liberto, E.; Sgorbini, B.; Rubiolo, P. 2007: Reliability of fibres in solid-phase microextraction for routine analysis of the headspace of aromatic and medicinal plants. J. Chromatogr. A, 1152(1-2): 138149. https://doi.org/10.1016/j.chroma.2007.02.011

7. Burdock, G. A.; Carabin, I. G., 2008: Safety assessment of Ylang-Ylang (Cananga spp.) as a food ingredient. Food Chem. Toxicol., 46: 433-445.

https://doi.org/10.1016/j.fct.2007.09.105

8. Deniz, I., 2013: Nonwood products industry (in Turkish), Lecture note. Karadeniz Technical University, Faculty of Forestry. Trabzon.

9. Fattore, E.; Benfenati, E.; Fanelli, R., 1996: Analysis of chlorinated 1,3-butadienes by solid-phase microextraction and gas chromatography-mass spectrometry. J. Chromatogr. A, (737): 85-91. https://doi.org/10.1016/0021-9673(95)01338-5

10. Gillette, N. E.; Hansen, E. M.; Mehmel, C. J.; Mori, S. R.; Webster, J. N.; Erbilgin N.; Wood, D. L., 2012. Areawide application of verbenone-releasing flakes reduces mortality of whitebark pine Pinus albicaulis caused by the mountain pine beetle Dendroctonus ponderosae. Agric. For. Entomol., 14: 367-375.

https://doi.org/10.1111/j.1461-9563.2012.00577.x

11. Hageman, K. J.; Mazeas, L.; Grabanski, C. B.; Miller, D. J.; Hawthorne, S. B., 1996: Coupled subcritical water extraction with solid-phase microextraction for determining semivolatile organics in environmental solids. Anal. Chem., 68 (22): 3892-3898. https://doi.org/10.1021/ac960751c

12. James, K. J.; Stack, M. A., 1996: The determination of volatile organic compounds in soils using solid phase mi- croextraction with gas chromatography. J. High Resolut. Chromatogr., 19: 515-519.

https://doi.org/10.1002/jhrc.1240190908

13. Jantam, I.; Ahmad, A. S., 1999: Oleoresins of three Pinus species from Malaysian pine plantations. ASEAN Review of Biodiversity and Environmental Conservation, $1-9$.

14. Limberger, R. P.; Aleixo, A. M.; Fett-Neto, A. G.; Henriques, A. T., 2007: Bioconversion of (+)- and (-)-alphapinene to (+)- and (-)-verbenone by plant cell cultures of Psychotria brachyceras and Rauvolfia sellowii. Electron. J. Biotechnol., 10: 500-507.

https://doi.org/10.2225/vol10-issue4-fulltext-8

15. Limberger, R. P.; Schuh, R. S.; Henriques, A. T., 2012: Pine terpene biotransformation. pp. 107-126; in: A. G. Fett-Neto; Rodrigues-Correa, K. C. S., eds. Pine resin: biology, chemistry and applications. Research Signpost, Kerala, India. ISBN: 978-81-308-0493-4.

16. Macchioni, F., Cioni, P. L.; Flamini, G.; Morelli, I.; Maccioni, S.; Ansaldi, M., 2003: Chemical composition of essential oils from needles, branches and cones of Pinus pinea, P. halepensis, P. pinaster and P. nigra from central Italy. Flavour Fragr. J., 18: 139-143. https://doi.org/10.1002/ffj.1178

17. Malik, A. K.; Kaur, V.; Verma, N., 2006: A review on solid phase microextraction - high performance liquid chromatography as a novel tool for the analysis of toxic metal ions. Talanta, 68 (3): 842-849.

https://doi.org/10.1016/j.talanta.2005.06.005

18. Mayekiso, B.; Magwa, M. L.; Coopoosamy, R. M., 2008: The chemical composition and antibacterial activity of the leaf extract of Salvia repens Burch. Ex Benth. J. Med. Plant Res., 2: 159-162. https://doi.org/10.5897/ajb2007.000-2377

19. McMorn, P.; Roberts, G.; Hutchings G. J., 2000: Oxidation of $\alpha$-pinene to verbenone using silica-titania co-gel catalyst. Catal. Lett., 67: 203-206. https://doi.org/10.1023/a:1019009403820

20. Mercier, B.; Prost, J.; Prost, M., 2009: The essential oil of turpentine and its major volatile fraction ( $\alpha$ and $\beta$-pinenes): a review. International Journal of Occupational Medicine and Environmental Health, 22 (4): 331342. https://doi.org/10.2478/v10001-009-0032-5

21. Mousavi, M.; Noroozian, E.; Jalali-Heravi, M.; Mollahosseini, A., 2007: Optimization of solid-phase microextraction of volatile phenols in water by a polyanilinecoated Pt-fiber using experimental design. Anal. Chim. Acta., 581: 71-77. https://doi.org/10.1016/j.aca.2006.08.001

22. Oz, M.; Deniz, I.; Komut, O.; Fidan, M. S., 2012: Resin butterfly (Dioryctria sylvestrella Ratz.) at red pine (Pinus brutia Ten.) and amounts of essential oils in stalk resins. KSU J. Nat. Sci., Special Issue: 89-95.

23. Oz, M.; Deniz, I.; Komut, O.; Fidan, M. S., 2015: Chemical composition of oleoresin and larvae gallery resin of Pinus brutia attacked by Dioryctria sylvestrella Ratz. Drvna industrija, 66(3): 179-188. https://doi.org/10.5552/ drind.2015.1408

24. Papajannopoulos, A. D.; Song, Z. Q.; Liang, Z. Q.; Spanos, J. A., 2001: GC-MS analysis of oleoresin of three Greek pine species. Eur. J. Wood Wood Prod., 59 (6): 443-446. https://doi.org/10.1007/s00107-001-0249-x

25. Penalver, A.; Pocurull, E.; Borrull, F.; Marce, R. M., 1999: Trends in solid-phase microextraction for determining organic pollutants in environmental samples. TrAC, Trends Anal. Chem., 18 (8): 557-568. https://doi.org/10.1016/s0165-9936(99)00145-4 
26. Polo, M.; Llompart, M.; Garcia-Jares, C.; Cela, R., 2005: Multivariate optimization of a solid-phase microextraction method for the analysis of phthalate esters in environmental waters. J. Chromatogr. A, 1072 (1): 63-72. https://doi.org/10.1016/j.chroma.2004.12.040

27. Rezzi, S.; Bighelli, A.; Castola, V.; Casanova, J., 2005: Composition and chemical variability of the oleoresin of Pinus nigra ssp. laricio from Corsica. Ind. Crops Prod., 21: 71-79. https://doi.org/10.1016/j.indcrop.2003.12.008

28. Roberge, D. M.; Buhl, D.; Niederer, J. P. M.; Holderich, W. F., 2001: Catalytic aspects in the transformation of pinenes to $p$-cymene. Appl. Catal. A, 215: 111-124. https://doi.org/10.1016/s0926-860x(01)00514-2

29. Rudback, J.; Bergstrom, M. A.; Borje, A.; Nilsson, U.; Karlberg, A. T., 2012: $\alpha$-Terpinene, an antioxidant in tea tree oil, autoxidizes rapidly to skin allergens on air exposure. Chem. Res. Toxicol., 25: 713-721. https://doi.org/10.1021/tx200486f

30. Sun, J., 2007: D-Limonene: safety and clinical applications. Altern. Med. Rev., 12: 259-264.

31. Teshome, T., 2011: Analysis of resin and turpentine oil constituents of Pinus patula grown in Ethiopia. Ee-JRIF, 3 (1): 38-48.

32. Tümen, I.; Reunanen, M., 2010: A comparative study on turpentine oils of oleoresins of Pinus sylvestris L. from three districts of Denizli. Records of Natural Products, 4 (4): 224.

33. Ulukanli, Z.; Karabörklü, S.; Bozok, F.; Burhan, A.; Erdogan, S.; Cenet, M.; Karaaslan, M. G., 2014: Chemical composition, antimicrobial, insecticidal, phytotoxic and antioxidant activities of Mediterranean Pinus brutia and
Pinus pinea resin essential oils. Chin J Nat Med., 12 (12): 901-910.

https://doi.org/10.1016/s1875-5364(14)60133-3

34. Wang, Z.; Calderon, M. M.; Carandang, M. G., 2006: Effects of resin tapping on optimal rotation age of pine plantation. J. Forest Eco., 11: 245-260. https://doi.org/10.1016/j.jfe.2005.10.001

35. Yasar, S.; Disli, M.; Sonkaya, Y., 2016: Comparison of volatile components of Thymus zygioides Griseb. var. lycaonicus (Celak.) Ronniger due to reaping time. Turk J For, 17 (2): 94-98. https://doi.org/10.18182/tjf.37096

36. Zhang, Z.; Pawliszyn, J., 1993: Headspace solid phase microextraction. Anal. Chem., 65: 1843-1852. https://doi.org/10.1021/ac00062a008

37. Zulak, K. G.; Bohlmann, J., 2010: Terpenoid biosynthesis and specialized vascular cells of conifer defense. J. Integr. Plant Biol., 52: 86-97. https://doi.org/10.1111/j.1744-7909.2010.00910.x

38. *** 2015: OGM Forest atlas (In Turkish). Ankara: General Directorate of Forestry.

\section{Corresponding address:}

\section{Prof. SAMIM YASAR, Ph.D.}

Department of Forest Products Engineering Faculty of Forestry, Isparta University of Applied Sciences 32260 Isparta, TURKEY

e-mail: samimyasar@isparta.edu.tr 